\title{
Prebiotic Properties of Epilactose
}

\author{
J. Watanabe, ${ }^{\star 1,2}$ M. Nishimukai, ${ }^{\star}$ H. Taguchi, ${ }^{*}$ T. Senoura, ${ }^{\star}$ S. Hamada,† H. Matsui,† T. Yamamoto,‡ J. Wasaki, ${ }^{\star}$ \\ H. Hara, $†$ and S. Ito* \\ *Creative Research Initiative "Sousei," Hokkaido University, Sapporo 001-0021, Japan \\ †Division of Applied Bioscience, Graduate School of Agriculture, Hokkaido University, Sapporo 060-8589, Japan \\ ¥Nihon Shokuhin Kako Co. Ltd., Shizuoka 417-8530, Japan
}

\begin{abstract}
We recently reported that cellobiose 2-epimerase from Ruminococcus albus effectively converted lactose to epilactose. In this study, we examined the biological effects of epilactose on intestinal microbiota, bile acid metabolism, and postadministrative plasma glucose by animal tests. Dietary supplementation with epilactose or fructooligosaccharide (4.5\% each) increased cecal wall weight and cecal contents and decreased the $\mathrm{pH}$ of the cecal contents in Wistar-ST rats. The number of total anaerobes tended to be greater in rats fed epilactose and fructooligosaccharide than in those fed the control diet. Lactobacilli and bifidobacteria were more numerous in rats fed epilactose and fructooligosaccharide diets than in those fed the control diet. Analysis of clone libraries of $16 \mathrm{~S}$ rRNA suggests that supplementation with epilactose did not induce the proliferation of harmful bacteria belonging to classes Clostridia or Bacteroidetes. Epilactose, as well as fructooligosaccharide, inhibited the conversion of primary bile acids to secondary bile acids, which are suggested to be promoters of colon cancer. In addition, oral administration of epilactose did not elevate the plasma glucose concentration in ddY mice. These results clearly indicate that epilactose is a promising prebiotic. We also showed that cellobiose 2-epimerase converted lactose in cow milk and a spray-dried ultrafiltrate of cheese whey to epilactose. Cellobiose 2-epimerase may increase the value of dairy products by changing lactose to epilactose possessing prebiotic properties.
\end{abstract}

Key words: epilactose, prebiotic, cellobiose 2-epimerase, whey

\section{INTRODUCTION}

Whey is a byproduct of cheese production. Although whey-containing diets reportedly improve growth per-

\footnotetext{
Received May 14, 2008.

Accepted August 5, 2008.

${ }^{1}$ Present address: Food Function Division, National Food Research Institute, 2-1-12 Kannondai, Tsukuba 305-8642 Japan.

${ }^{2}$ Corresponding author: nabej@affrc.go.jp
}

formance of weanling pigs (Grinstead et al., 2000), cheese whey is not effectively used. Lactose is the main solid constituent of cheese whey, and its concentration in cow milk reaches $4.4 \%$. Although direct utilization of lactose is thought to be difficult because of its low sweetening power and solubility, various attempts have been made to increase the use of cheese whey. Enzymatic hydrolysis of lactose by $\beta$-galactosidase has been used industrially to produce food materials or microbial substrates (Becerra et al., 2004). Lactose can be chemically converted to lactulose (Méndez and Olano, 1979). Lactulose specifically promotes the intestinal proliferation of bifidobacteria, which is known to be a very important humanizing factor in infant formula, and it has been added to commercial infant products (Méndez and Olano, 1979).

Some bacteria, such as Lactobacillus and Bifidobacterium spp., which have been described as living microorganisms exerting health benefits, exemplify the concept of probiotics (Guarner and Schaafsma, 1998). They have been reported to prevent and treat rotavirus infections and postantibiotic diarrhea (Shornikova et al., 1997), allergic diseases (Kalliomaki et al., 2001), and inflammatory bowel disease (Rembacken et al., 1999). Growth of beneficial intestinal bifidobacteria can be stimulated by dietary supplementation with prebiotics (Cummings and MacFarlane, 2002). For example, fructooligosaccharide (FOS), a polymer of fructose found in artichokes, leeks, asparagus, onions, and bananas and one of the most widely used nondigestive oligosaccharides, stimulates the growth of fecal bifidobacteria in healthy human subjects (Langlands et al., 2004) and mice (Ohta et al., 2002). Several studies indicate that through fortification with beneficial microflora, prebiotics may enhance the defense mechanisms of host animals, increase resistance to various health challenges, and accelerate recovery from gastrointestinal tract disturbances (Buddington et al., 2002).

Tyler and Leatherwood (1967) described an enzyme activity in the culture broth of Ruminococcus albus 7 $\left(\right.$ ATCC $27210^{\mathrm{T}}$ ) that mediates the epimerization of cellobiose and named it cellobiose 2-epimerase (CE, EC 5.1.3.11). This enzyme epimerizes cellobiose and gener- 
ates 4- $O$ - $\beta$-D-glucopyranosyl-D-mannose in a reversible manner. Ito et al. (2007) described the purification of $\mathrm{CE}$ from $R$. albus NE1 and the cloning and sequencing of the corresponding gene. We recently reported that CE from $R$. albus NE1 reacts not only with cellooligosaccharides but also with lactose, yielding 4-O- $\beta$ D-galactopyranosyl-D-mannose (epilactose; Ito et al., 2008). Although heat-treated cow milk contains a trace amount of epilactose (Moreno et al., 2003), its biological activities have not yet been clarified to date. The aim of this work was to evaluate the biological activities of epilactose, which was easily synthesized from lactose by the action of CE.

\section{MATERIALS AND METHODS}

\section{Preparation of Epilactose}

Lactose was treated with recombinant $\mathrm{CE}$ according to the method of Ito et al. (2008). Epilactose was separated from the resulting reaction mixture by HPLC. A Shodex Sugar SP0810 column $(8.0 \times 300 \mathrm{~mm}$, Shodex, Tokyo, Japan) was used, and elution was done with distilled water. The fractions containing epilactose were collected and lyophilized. For rat feeding, 90\% pure epilactose was used, and $>98 \%$ pure epilactose was used for the other experiments.

\section{Feeding Study of Rats}

Casein and sucrose were purchased from the New Zealand Dairy Board (ALACID, Wellington, New Zealand) and Nihon Beet Sugar Manufacturing Co. (Tokyo, Japan), respectively. Lactose, L-cystine, choline bitartrate, and $t$-butylhydroquinone were the products of Wako Pure Chemical Industries (Osaka, Japan). Corn oil, crystalline cellulose, and FOS (Meioligo P) were purchased from Ajinomoto Co. (Tokyo, Japan), Advantec Toyo (Tokyo, Japan), and Meiji Foodmateria (Tokyo, Japan), respectively.

Four-week-old male Wistar-ST rats were purchased from Japan SLC (Hamamatsu, Japan) and housed in individual cages in a temperature-controlled room (23 $\pm 2^{\circ} \mathrm{C}$ ) with a dark period from 2000 to $0800 \mathrm{~h}$. They were allowed free access to an AIN93G composition diet (Reeves et al., 1993) and water before the experiment. After consuming the AIN93G diet for $5 \mathrm{~d}$, rats weighing $113.6 \pm 0.9 \mathrm{~g}(\mathrm{n}=24)$ were divided into 4 groups of 6 animals. Each group of rats was fed the control, lactose, epilactose, or FOS diet. The diet compositions were based on the report of Hara et al. (1998) except for adding $5 \%$ of crystalline cellulose. The lactose, epilactose, and FOS diets were prepared by adding $50 \mathrm{~g}$ of lactose or epilactose or $45 \mathrm{~g}$ of FOS to each kilogram of the control diet by substituting for sucrose, respectively. To adjust the lactose concentrations of the control, epilactose, and FOS diets, $5 \mathrm{~g}$ of lactose per kilogram was substituted for sucrose in the control and FOS diets. Rats were fed each diet ad libitum for $15 \mathrm{~d}$, and then they were anesthetized by an intraperitoneal injection of Nembutal (sodium pentobarbital, $50 \mathrm{mg} / \mathrm{kg}$ of BW; Abbott Laboratories, Abbott Park, IL). After laparotomy, rats were killed by bleeding from the abdominal aorta. Proximal and distal sites of the cecum were tied, and cecum with its contents was removed.

Animal tests were approved by the Hokkaido University Animal Use Committee, and animals were maintained in accordance with the guidelines for the care and use of laboratory animals at Hokkaido University.

\section{Quantification of Intestinal Bacteria by Culture Method}

Total anaerobes of rat cecal contents were quantified according to the method of Mitsuoka et al. (1965). Briefly, cecal contents were immediately diluted in 10-fold steps with anaerobic phosphate buffer, and 50 $\mu \mathrm{L}$ of each dilution was inoculated on BL agar (Eiken Chemical, Tokyo, Japan) containing $5 \%$ (vol/vol) horse blood (Nihon Biotest, Tokyo, Japan). The plates were incubated anaerobically at $37^{\circ} \mathrm{C}$ for $24 \mathrm{~h}$ by the gas pack method, and the number of colonies formed was counted.

\section{Quantification of Bifidobacteria and Lactobacilli by Real-Time PCR}

Deoxyribonucleic acid was extracted from cecal contents using a Fecal DNA Isolation Kit (MO Bio Laboratories, Carlsbad, CA; Stevenson et al., 2004) according to the instructions of the manufacturer. Amplification and detection of cecal DNA were performed with a Smart Cycler II (Cepheid, Sunnyvale, CA) according to our previous report (Watanabe et al., 2008). Bifidobacterium genus-specific (forward: TCG CGT $\mathrm{C}(\mathrm{C} / \mathrm{T}) \mathrm{G}$ GTG TGA AAG, reverse: CCA CAT CCA GC(A/G) TCC AC, Rinttilä et al., 2004) and Lactobacillus genusspecific (forward: TGG AAA CAG (A/G)TG CTA ATA CCG, reverse: GTC CAT TGT GGA AGA TTC CC, Byun et al., 2004) primer pairs were used.

\section{Analysis of the 16S rRNA Sequences of Cecal Bacteria}

Cecal DNA samples were pooled and used as a template to amplify the fragments of $16 \mathrm{~S}$ rRNA with the universal primers U968 (AAC GCG AAG AAC CTT AC) and L1401 (CGG TGT GTA CAA GAC CC) (Zo- 
etendal et al., 2002). Polymerase chain reaction was performed in a reaction volume of $25 \mu \mathrm{L}$ that contained $500 \mathrm{n} M$ each of U968 and L1401, $1 \times$ PCR buffer, $0.2 \mathrm{~m} M$ each of deoxynucleoside triphosphate, and 1.25 U of Taq-HS polymerase (Takara, Otsu, Japan). The reaction conditions were $94^{\circ} \mathrm{C}$ for $5 \mathrm{~min}$, followed by 12 cycles of $94^{\circ} \mathrm{C}$ for $30 \mathrm{~s}, 56^{\circ} \mathrm{C}$ for $20 \mathrm{~s}$, and $68^{\circ} \mathrm{C}$ for 40 $\mathrm{s}$, and final extension at $68^{\circ} \mathrm{C}$ for $7 \mathrm{~min}$. The amplicons were purified by a GFX PCR DNA and Gel Band Purification Kit (GE Healthcare Bioscience, Piscataway, NJ; Marko et al., 1982) and cloned into pGEM-T Easy vector (Promega, Madison, WI). Competent Escherichia coli XL-1 Blue cells were transformed with the constructed vectors, and the transformants were plated onto Luria-Bertani agar plates supplemented with $25 \mu \mathrm{g} / \mathrm{mL}$ of ampicillin, $30 \mu \mathrm{g} / \mathrm{mL}$ of 5 -bromo-4chloro-3-indolyl- $\beta$-D-galactopyranoside, and $20 \mu \mathrm{g} / \mathrm{mL}$ of isopropyl- $\beta$-D-thiogalactopyranoside and incubated overnight at $37^{\circ} \mathrm{C}$. White colonies were picked up and grown on Luria-Bertani agar. Plasmid DNA was amplified with an Illustra TempliPhi DNA amplification Kit (GE Healthcare Bioscience; Dean et al., 2001) according to the instructions of the manufacturer. Resulting amplicons were sequenced by using an ABI3730XL or ABI3730 automatic sequencer (Applied Biosystems, Foster City, CA) with M13-F (GTT TTC CCA GTC ACG ACG TT) as the sequencing primer.

All sequences were examined for possible chimeric artifacts by the CHECK CHIMERA program of the Ribosomal Database Project (Maidak et al., 2001) and compared with similar sequences of the reference organisms by a BLAST search (Altschul et al., 1990) and the SIMILARITYRANK program (Maidak et al., 2001). Classification of bacteria based on their sequences was done by the Classifier program of Ribosomal Database Project, setting the threshold value at $80 \%$.

\section{Analysis of Bile Acids}

Cholic acid, deoxycholic acid (DCA), chenodeoxycholic acid (CDCA), lithocholic acid, ursodeoxycholic acid, and hyodeoxycholic acid (HDCA) were obtained from Sigma (St. Louis, MO). $\alpha$-Muricholic acid (MCA) and $\beta$-MCA were obtained from Steraloids (Newport, RI), and 23-nordeoxycholic acid (NDCA) was from ICN Biomedicals (Costa Mesa, CA).

Concentrations of bile acids in cecal contents were determined by the method of Minamida et al. (2005) with modifications. Briefly, homogenized cecal contents (approximately $50 \mathrm{mg}$ ) were suspended in $1.5 \mathrm{~mL}$ of ethanol containing $1 M \mathrm{NaOH}$ and $50 \mathrm{nmol}$ of NDCA (internal standard), and bile acids were extracted twice at $80^{\circ} \mathrm{C}$ for $1 \mathrm{~h}$. The resulting extracts were applied to an Oasis HLB column (Japan Waters, Tokyo, Japan) and eluted by ethanol. The eluates were methylated with trimethylsilyl-diazomethane and then silylated with BSA+TMCS+TMSI (Sigma). Injections were made at $270^{\circ} \mathrm{C}$, and derivatized bile acids were separated and quantified by GC-MS (1200L; Varian Inc., Palo Alto, CA) equipped with a capillary column (TC-5, $30 \mathrm{~m} \times$ $0.25 \mathrm{~mm}$; GL Science, Tokyo, Japan), using purified helium gas as a carrier gas. The column temperature was programmed to remain at $240^{\circ} \mathrm{C}$ for $2 \mathrm{~min}$, to increase to $290^{\circ} \mathrm{C}$ at a rate of $10^{\circ} \mathrm{C} / \mathrm{min}$, and then remain at $290^{\circ} \mathrm{C}$ for $25 \mathrm{~min}$. The ions selected for the different bile acids were $m / z 253,368$ for cholic acid; $m / z 255$, 370 for DCA; $m / z 355,370$ for CDCA; $m / z 215,372$ for lithocholic acid; $m / z$ 370, 460 for ursodeoxycholic acid; $m / z$ 405, 460 for HDCA; $m / z$ 443, 458 for $\alpha$-MCA; $m / z 195,285$ for $\beta$-MCA; and $m / z 255,356$ for NDCA. Quantification was carried out by a correction factor obtained using NDCA as an internal standard.

\section{Plasma Glucose Changes After Oral Epilactose Administration in Mice}

Plasma glucose concentrations after oral epilactose administration were determined essentially by the method of Yamazaki et al. (2007). Five-week-old female ddY mice were purchased from Japan SLC and housed in standard plastic cages in a temperature-controlled room $\left(23 \pm 2^{\circ} \mathrm{C}\right)$. They were allowed free access to commercial chow (Labo MR Stock, Nihon Nosan Kogo Co., Yokohama, Japan) and water. After an overnight fasting, they were orally administered $0.15 \mathrm{mmol}$ of epilactose or lactose dissolved in $200 \mu \mathrm{L}$ of tap water. Blood was collected from the tail vein 30, 60, and 120 min after the administration, and the plasma glucose concentration was determined by using a commercial glucose oxidase kit (Wako Pure Chemical Industries) according to the instructions of the manufacturer.

\section{CE Treatment of Cow Milk and Cheese Whey}

Purification of recombinant CE of $R$. albus NE1 was performed according to the method of Ito et al. (2007). Cow milk was purchased from a retail source, and a spray-dried ultrafiltrate of cheese whey (permeate) was kindly provided by Meiji Dairies Co. (Tokyo, Japan). Ten milliliters of $1 \%$ (wt/vol) permeate (adjusted $\mathrm{pH}$ to 7.5 by $\mathrm{NaOH}$ ) and cow milk were each treated with 20 $\mu \mathrm{L}$ of recombinant $\mathrm{CE}$ (containing $30 \mu \mathrm{g}$ of purified $\mathrm{CE}$ ) at $10^{\circ} \mathrm{C}$. One, 3,5 , and $10 \mathrm{~h}$ after starting the reaction, aliquots of the reactant were removed and immediately boiled for $5 \mathrm{~min}$. The reaction mixtures $(1 \mu \mathrm{L}$ each) were spotted onto a thin-layer chromatography plate (Silica gel 60; Merck, Darmstadt, Germany) and developed in a solvent system of 2-propanol/1-butanol $/ \mathrm{H}_{2} \mathrm{O}$ 
(12:3:4, by volume). The chromatogram was developed by color reaction with the anisaldehyde-sulfuric acid procedure.

\section{Statistical Analyses}

Results are presented as means \pm standard error of the means. The paired and unpaired $t$-test or TukeyKramer test after 1-way ANOVA was used to compare mean values. Data analysis was performed with StatView for Macintosh (version 5.0, SAS Institute Inc., Cary, NC). The $P$-values less than 0.05 were considered statistically significant.

\section{RESULTS}

\section{Feeding Study of Rats}

$B W$ Change and Food Intake. The initial BW of the 4 groups were the same and averaged $113.6 \pm 0.9 \mathrm{~g}$. Body weight gains over $15 \mathrm{~d}$ were the same, $99.8 \pm 4.8$ $\mathrm{g}, 100.6 \pm 4.0 \mathrm{~g}, 104.0 \pm 2.7 \mathrm{~g}$, and $104.1 \pm 4.3 \mathrm{~g}$, for rats fed the control, lactose, epilactose, and FOS diets, respectively. Total food intakes over $15 \mathrm{~d}$ were the same, $259.3 \pm 7.3 \mathrm{~g}, 260.0 \pm 4.7 \mathrm{~g}, 257.7 \pm 7.4 \mathrm{~g}$, and 258.8 $\pm 3.5 \mathrm{~g}$, for rats fed the control, lactose, epilactose, and FOS diets, respectively. Average intake was calculated to be $4.76 \mathrm{~g} / \mathrm{kg}$ of $\mathrm{BW}$ per day for epilactose and 4.75 $\mathrm{g} / \mathrm{kg}$ of BW per day for FOS.

Cecal Fermentation Parameters. Cecal wall weights of rats fed the epilactose and FOS diets were $3.8 \pm 0.2$ and $3.5 \pm 0.2 \mathrm{~g} / \mathrm{kg}$ of $\mathrm{BW}$, respectively, and they were significantly greater than those of rats fed the control $(2.3 \pm 0.2 \mathrm{~g} / \mathrm{kg}$ of $\mathrm{BW})$ and lactose $(2.4 \pm$ $0.1 \mathrm{~g} / \mathrm{kg}$ of BW) diets. Cecal content weights of rats fed the epilactose and FOS diets were $22.9 \pm 0.9$ and $16.7 \pm 1.8 \mathrm{~g} / \mathrm{kg}$ of $\mathrm{BW}$, respectively, and they were significantly greater than those of rats fed the control
$(7.8 \pm 0.9 \mathrm{~g} / \mathrm{kg}$ of BW $)$ and lactose $(10.0 \pm 1.1 \mathrm{~g} / \mathrm{kg}$ of BW) diets. The cecal content $\mathrm{pH}$ values of rats fed the epilactose and FOS diets were $6.61 \pm 0.22$ and 6.88 \pm 0.22 , respectively, and they were significantly lower than those of rats fed the control $(7.57 \pm 0.04)$ and lactose $(7.54 \pm 0.08)$ diets.

Cecal Bacteria Numbers. Quantification of total cecal anaerobes was performed by a culture method, and quantification of lactobacilli and bifidobacteria was performed by real-time PCR using genus-specific primers. The numbers of total cecal anaerobes in epilactosefed rats tended to be greater, and those in FOS-fed rats were significantly greater than those in control rats (Figure 1A). The numbers of cecal lactobacilli in epilactose- and FOS-fed rats were significantly greater than those in control rats (Figure 1B). Detectable concentrations of bifidobacteria were observed in all cecal DNA samples from epilactose- and FOS-fed rats, although they were at low concentrations in 5 out of 6 samples from control rats and in 4 out of 6 samples from lactosefed rats. The logarithmic cecal bifidobacteria numbers of rats fed the epilactose and FOS diets reached 7.80 \pm 0.28 and $8.68 \pm 0.24$ copies/g, respectively, and they were significantly greater than those fed the control and lactose diets (Figure 1C).

Comparison of Bacterial Populations. For the comparison of intestinal microbiota, 16S rRNA libraries were constructed from cecal DNA of rats using universally conserved $16 \mathrm{~S}$ rRNA-targeted primers. Eighty-eight, 111, 98, and 100 clones were randomly selected from the libraries of control, lactose-, epilactose-, and FOS-fed rats, respectively, and their sequences were determined. Based on the sequence similarities, the clones were classified into several clusters corresponding to classes of the domain Bacteria (Table 1). The populations of clones classified into the classes $\delta$-Proteobacteria and Clostridia tended to be smaller in epilactose- and FOS-fed rats than in control and
A



B

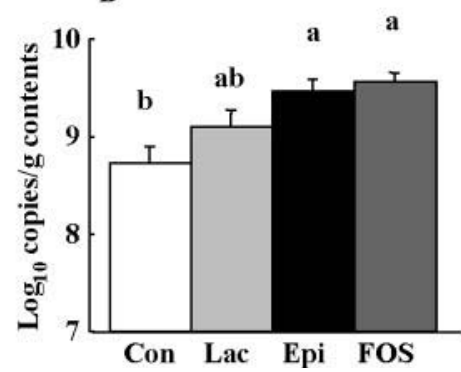

C

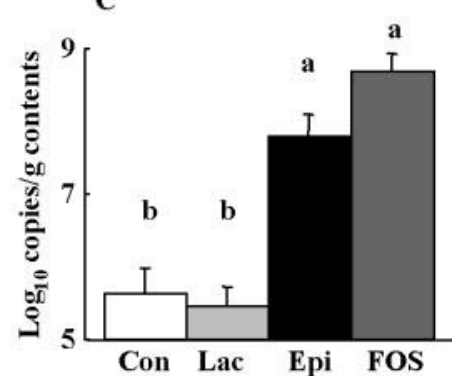

Figure 1. Numbers of total (A) anaerobes, (B) lactobacilli, and (C) bifidobacteria in the cecal contents of rats fed the control (Con), lactose (Lac), epilactose (Epi), or fructooligosaccharide (FOS) diet. Quantification of total anaerobes was done by a culture method, whereas quantification of lactobacilli and bifidobacteria was done by real-time PCR. Numbers of total anaerobes, lactobacilli, and bifidobacteria are shown as logarithmic colony-forming units per gram and logarithmic copies per gram, respectively. Different letters show significant differences among the groups. 
Table 1. Distribution of $16 \mathrm{~S}$ rRNA in cecal samples of rats fed the control, lactose, epilactose, or fructooligosaccharide (FOS) diet

\begin{tabular}{|c|c|c|c|c|}
\hline Item & Control & Lactose & Epilactose & FOS \\
\hline & & Number & nes $(\%)$ & \\
\hline \multicolumn{5}{|l|}{ Deferribacteres } \\
\hline Deferribacteres & $1(1.1)$ & $0(0)$ & $0(0)$ & $0(0)$ \\
\hline \multicolumn{5}{|l|}{ Proteobacteria } \\
\hline$\gamma$-Proteobacteria & $1(1.1)$ & $13(11.7)$ & $0(0)$ & $0(0)$ \\
\hline$\beta$-Proteobacteria & $1(1.1)$ & $4(3.6)$ & $9(9.2)$ & $9(7.0)$ \\
\hline$\delta$-Proteobacteria & $5(5.7)$ & $8(7.2)$ & $0(0)$ & $1(1.0)$ \\
\hline$\varepsilon$-Proteobacteria & $2(2.3)$ & $0(0)$ & $0(0)$ & $1(1.0)$ \\
\hline \multicolumn{5}{|l|}{ Firmicutes } \\
\hline Bacilli & $3(3.4)$ & $3(2.7)$ & $6(6.1)$ & $9(9.0)$ \\
\hline Clostridia & $38(43.2)$ & $45(40.5)$ & $24(24.5)$ & $27(27.0)$ \\
\hline Mollicutes & $5(5.7)$ & $7(6.3)$ & $9(9.2)$ & $14(14.0)$ \\
\hline Others & $5(5.7)$ & $10(9.0)$ & $21(21.4)$ & $15(15.0)$ \\
\hline \multicolumn{5}{|l|}{ Bacteroidetes } \\
\hline Bacteroidetes & $24(27.3)$ & $16(14.4)$ & $22(22.4)$ & $20(20.0)$ \\
\hline \multicolumn{5}{|l|}{ Actinobacteria } \\
\hline Actinobacteria & $0(0)$ & $0(0)$ & $3(3.1)$ & $4(4.0)$ \\
\hline Unclassified bacteria & $3(3.4)$ & $5(4.5)$ & $4(4.1)$ & $2(2.0)$ \\
\hline Total & $88(100)$ & $111(100)$ & $98(100)$ & $100(100)$ \\
\hline
\end{tabular}

lactose-fed rats. On the other hand, the populations of the classes Bacilli and Actinobacteria tended to be greater in epilactose- and FOS-fed rats than in control and lactose-fed rats.

Bile Acid Composition of Cecal Contents. Concentrations of primary and secondary bile acids in cecal contents were determined by GC-MS after derivatization (Table 2). Cecal $\alpha$-MCA was significantly greater in rats fed lactose, epilactose, and FOS diets than that in those fed the control diet. Cecal $\beta-\mathrm{MCA}$ of lactose-fed rats tended to be greater and that of epilactose- and FOS-fed rats was significantly greater than that of control rats. The sum of the primary bile acids determined was significantly greater in rats fed lactose, epilactose, and FOS diets than in those fed the control diet. Cecal DCA was significantly greater in lactose- and epilactose-fed rats than that in control rats. Negligible concentrations of HDCA were observed in epilactose- and FOS-fed rats, although detectable concentrations were observed in control and lactose-fed rats. The sum of the secondary bile acids was significantly greater in rats fed the lactose diet than in those fed the control, epilactose, and FOS diets. The ratio of primary bile acids to secondary bile acids was significantly greater in epilactose- and FOS-fed rats than that in control and lactose-fed rats.

Table 2. Composition of cecal bile acids ${ }^{1}$

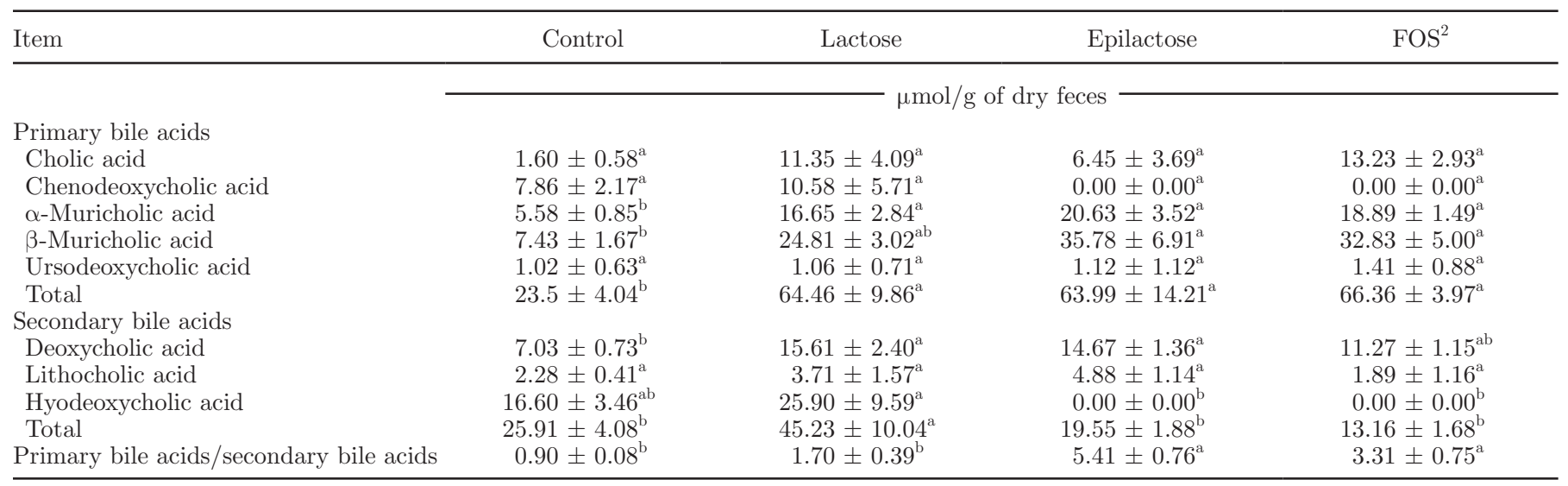

${ }^{a, b}$ Means without common letter differ $(P<0.05)$.

${ }^{1}$ Values are means $\pm \operatorname{SEM}(\mathrm{n}=6)$.

${ }^{2} \mathrm{FOS}=$ fructooligosaccharide. 


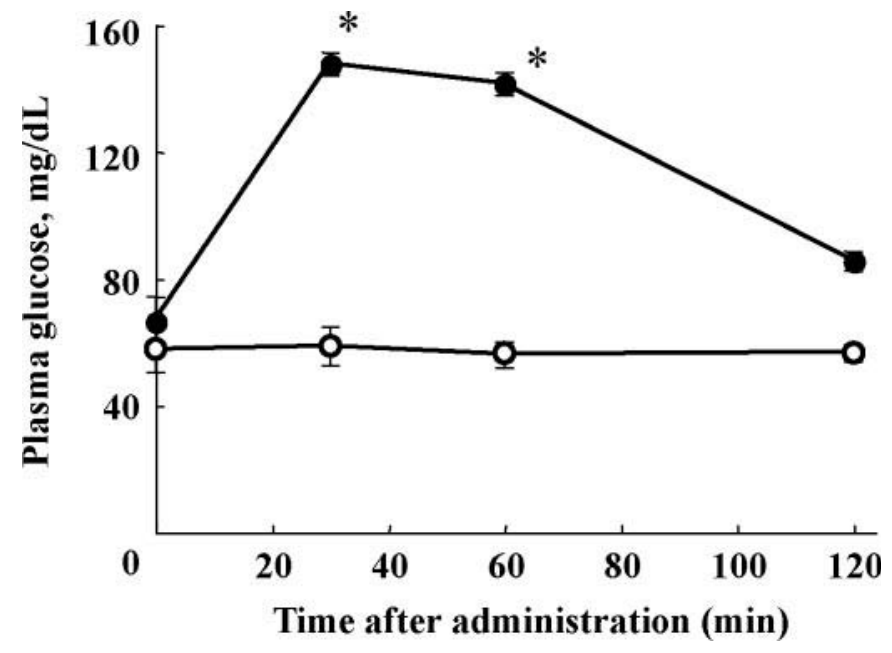

Figure 2. Time course of plasma glucose concentrations in ddY mice after oral administration of epilactose (open circles) or lactose (filled circles). Female ddY mice were orally administered $0.15 \mathrm{mmol}$ of epilactose or lactose dissolved in $200 \mu \mathrm{L}$ of tap water, and plasma glucose concentrations were determined 30,60, and 120 min after the administration. Asterisks show significant differences when compared with $0 \mathrm{~min}$.

\section{Plasma Glucose Change After Oral Administration in Mice}

Epilactose or lactose was administered orally to mice, and the time course of changes in the plasma glucose concentration was determined (Figure 2).
Plasma glucose concentrations before oral administration were almost the same in both groups of mice. In the lactose-administered mice, significant elevations in plasma glucose were observed at 30 and $60 \mathrm{~min}$, but the concentration returned to normal at $120 \mathrm{~min}$. In contrast, oral epilactose administration did not induce a significant change in plasma glucose at least up to 120 min after administration.

\section{Preparation of Epilactose from Dairy Products}

Cow milk and permeate were treated with recombinant $\mathrm{CE}$, and the products were determined by thin-layer chromatography. The spots corresponding to epilactose increased with reaction time when both cow milk and permeate were treated with CE (Figure 3). Under the standard conditions of enzyme assay, the reaction reached equilibration with conversion rate from lactose to epilactose of approximately $40 \%$, which is almost the same as the value obtained with lactose and CE from R. albus NE1 (Ito et al., 2008).

\section{DISCUSSION}

Prebiotics are compounds, usually carbohydrates, that are resistant to direct metabolism by the host and reach the lower gastrointestinal tract where they are preferentially utilized by selected groups of ben-
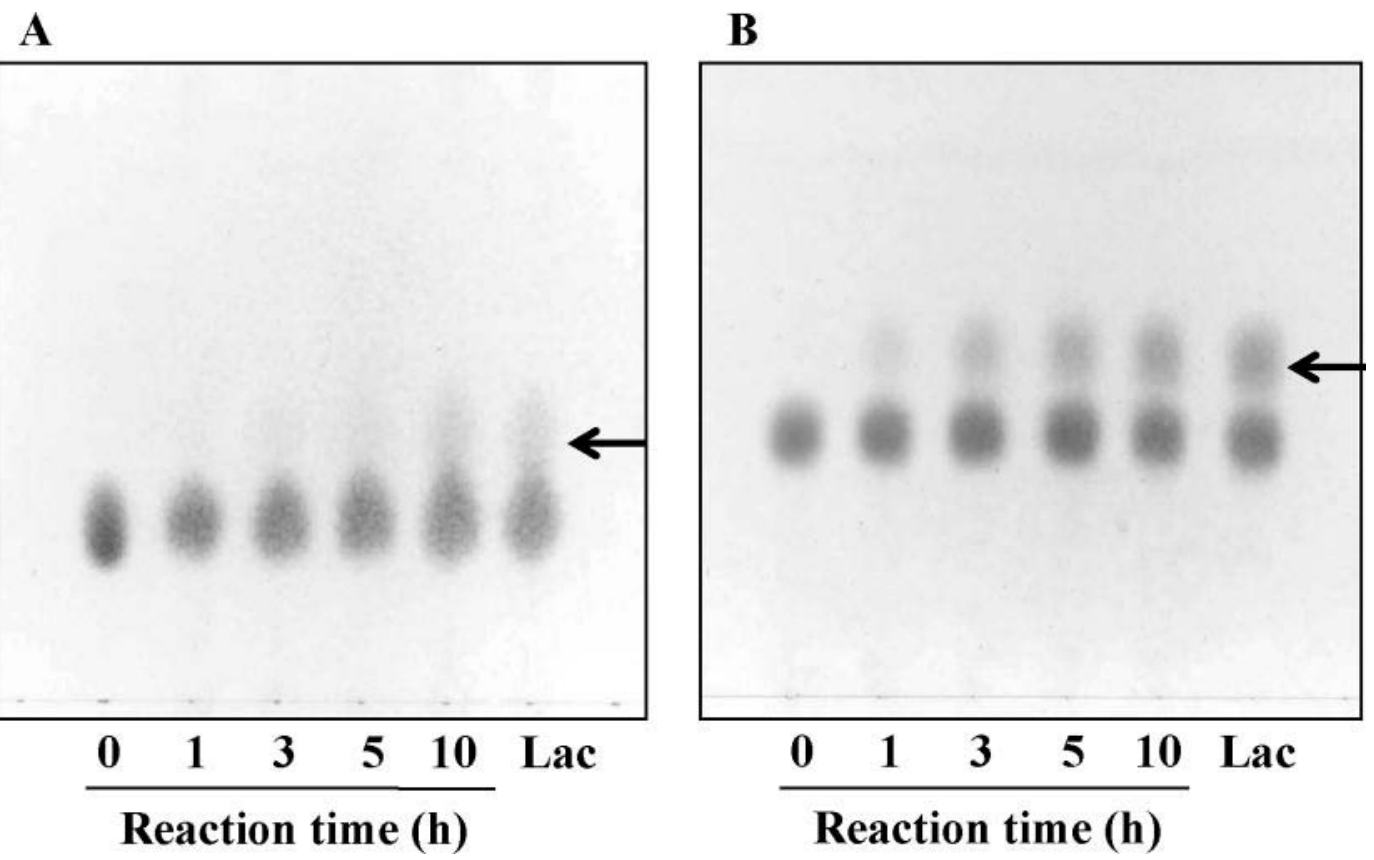

Figure 3. Thin-layer chromatography profiles of cellobiose 2-epimerase (CE) products of (A) dairy milk and (B) permeate. Cow milk and permeate were treated with $\mathrm{CE}$ at $10^{\circ} \mathrm{C}$ for $1,3,5$, and $10 \mathrm{~h}$. The chromatograms were developed by the anisaldehyde-sulfuric acid procedure. Lac $=$ CE product of lactose. Arrows show the spots corresponding to epilactose. 
eficial bacteria such as bifidobacteria and lactobacilli (Ziemer and Gibson, 1998). In this study, we examined the biological activities of epilactose with lactose and FOS as references, using Wistar-ST rats. There were no significant differences in food intake and BW gain among all groups of rats, and average epilactose and FOS intake was 4.76 and $4.75 \mathrm{~g} / \mathrm{kg}$ of $\mathrm{BW}$ per day, respectively. In addition, epilactose has no toxic effect as far as $4.76 \mathrm{~g} / \mathrm{kg}$ of BW per day (data not shown). Importantly, the feeding study revealed that supplementation of epilactose induced proliferation not only of total anaerobes but also of bifidobacteria and lactobacilli in the cecum (Figure 1). We reported that epilactose resists gastrointestinal digestion in vitro (Ito et al., 2008), suggesting that epilactose reaches the lower gastrointestinal tract without being digested, where it is utilized by bifidobacteria and lactobacilli. Further, ingestion of epilactose did not induce an increase of harmful bacteria belonging to the classes Clostridia and Bacteroidetes (Table 1). These results suggest that epilactose, like FOS, changes the intestinal flora in a beneficial way. It is well known that bifidobacteria and lactobacilli ferment various kinds of sugars to produce organic acids (Bezkorovainy, 1989). Fructooligosaccharide, a typical prebiotic, increases cecal wall weight by increasing organic acid concentrations in the cecum (Gudiel-Urbano and Goñi, 2002). Indeed, in FOS- as well as epilactose-fed rats, cecal wall weights and cecal content weights were significantly greater than those in control and lactose-fed rats. These results suggest that cecal epithelial cells are proliferated by short-chain fatty acids, which are derived from alteration in intestinal microbiota by epilactose and FOS.

Primary bile acids were significantly greater in rats fed lactose, epilactose, and FOS diets than in those fed the control diet (Table 2). Secondary bile acids were almost the same in rats fed the control, epilactose, and FOS diets, although significantly greater amounts were observed in rats fed the lactose diet. These results suggest that supplementation of the diet with lactose, epilactose, or FOS increases bile acid synthesis in the liver, increases enterohepatic circulation of bile acids, or both, and that supplementation with epilactose or FOS inhibits the conversion of primary bile acids to secondary bile acids by intestinal bacteria. It has been reported that the major biliary bile acids in rats are tauroconjugated cholic acid, CDCA, $\alpha-\mathrm{MCA}$, and $\beta$-MCA (Uchida et al., 1999). These primary bile acids are thought to biotransform to secondary bile acids by intestinal bacteria (Groh et al., 1993). Deoxycholic acid is the $7 \alpha$-dehydroxylation product of cholic acid, and HDCA is thought to be derived from $\beta$-MCA (Eyssen et al., 1999). Eyssen et al. (1999) reported that an unidentified gram-positive rod, HDCA-1, whose $16 \mathrm{~S}$
rRNA sequence showed the greatest similarity to that of Termitobacter aceticus (89.6\%), converted $\beta$-MCA to HDCA and that the monointroduction of strain HDCA-1 into germ-free rats facilitated the conversion of $\beta$-MCA to HDCA. In the present study, cecal HDCA concentrations in rats fed the epilactose and FOS diets were under the detection limit, but a significant increase of cecal $\beta$-MCA was observed in these rats (Table 2 ). In addition, clone library analysis of $16 \mathrm{~S}$ rRNA revealed that the class Clostridia tended to be fewer in these rats than in the control and lactose-fed rats (Table 2 ). In rats fed the epilactose and FOS diets, the cecal content $\mathrm{pH}$ was below 7 , in which the proliferation of strain HDCA-1 was completely abolished (Eyssen et al., 1999). These results suggest that epilactose decreases the population of the class Clostridia, which possesses the ability to convert $\beta$-MCA to HDCA. Secondary bile acids are cytotoxic to colon cells and have been implicated as tumor promoters (Hori et al., 1998). Hsu et al. (2004) reported that ingestion of a nondigestible oligosaccharide decreased the conversion to secondary bile acids and decreased 1,2-dimethylhydrazine-induced precancerous colon lesions in rats. Taken together, it is possible that ingestion of epilactose suppresses colon cancer by inhibiting the formation of secondary bile acid by the change in intestinal microbiota.

Oral administration of epilactose did not elevate plasma glucose concentrations in mice (Figure 2). It is easily understood that epilactose may not elevate plasma glucose in rats, because it is resistant to intestinal enzymes of rats (Ito et al., 2008). This result suggests that the increase of plasma glucose induced by dairy product ingestion can be decreased by $\mathrm{CE}$ treatment.

Lactulose possesses a bifidogenic effect and is industrially produced from lactose (Sako et al., 1999). The synthetic protocol for the production of lactulose includes expensive separation and purification steps to remove by-products, because alkaline or complex reagents such as aluminate and borate are used (Lee et al., 2004). In contrast, the reaction mixture of $\mathrm{CE}$ contains only epilactose and lactose as sugar ingredients. This means that $\mathrm{CE}$ converted part of the lactose in cow milk or a spray-dried ultrafiltrate of cheese whey to epilactose without any purification steps (Figure 3). Thus, CE can increase the values of lactose, cheese whey, and milk by preparing novel dairy products having prebiotic properties.

\section{ACKNOWLEDGMENTS}

Purified epilactose was kindly provided by M. Takada and T. Nakakuki of Nihon Shokuhin Kako Co. Ltd. This study was supported by Special Coordination Funds for 
Promoting Science and Technology and by a National Project "Knowledge Cluster Initiative" (second stage, "Sapporo Biocluster Bio-S") from the Ministry of Education, Science, Sports and Culture of Japan.

\section{REFERENCES}

Altschul, S. F., W. Gish, W. Miller, E. W. Myers, and D. J. Lipman. 1990. Basic local alignment search tool. J. Mol. Biol. 215:403410.

Becerra, M., E. Rodríguez-Belmonte, M. E. Cerdán, and M. I. G. Siso. 2004. Engineered autolytic yeast strains secreting Kluyveromyces lactis $\beta$-galactosidase for production of heterologous proteins in lactose media. J. Biotechnol. 109:131-137.

Bezkorovainy, A. 1989. Nutrition and metabolism of bifidobacteria. Pages 93-129 in Biochemistry and Physiology of Bididobacteria. R. Miller-Catchpole and A. Bezkorovainy, ed. CRC Press, Boca Raton, FL

Buddington, R. K., K. Quagliana, K. K. Buddington, and Y. Kimura. 2002. Non-digestive oligosaccharides and defence functions: Lessons learned from animal models. Br. J. Nutr. 87:S231-S239.

Byun, R., M. A. Nadkarni, K. L. Chhour, F. E. Martin, N. A. Jacques, and N. Hunter. 2004. Quantitative analysis of diverse Lactobacillus species present in advanced dental caries. J. Clin. Microbiol. $42: 3128-3136$

Cummings, J., and G. MacFarlane. 2002. Gastrointestinal effects of prebiotics. Br. J. Nutr. 87:S145-S151.

Dean, F. B., J. R. Nelson, T. L. Giesler, and R. S. Lasken. 2001. Rapid amplification of plasmid and phage DNA using Phi29 DNA polymerase and multiply-primed rolling circle amplification. Genome Res. 11:1095-1099.

Eyssen, H. J., G. de Pauw, and J. van Eldere. 1999. Formation of hyodeoxycholic acid from muricholic acid and hyocholic acid by an unidentified gram-positive rod termed HDCA-1 isolated from rat intestinal microflora. Appl. Environ. Microbiol. 65:3158-3163.

Grinstead, G. S., R. D. Goodband, S. S. Dritz, M. D. Tokach, J. L. Nelssen, J. C. Woodworth, and M. Molitor. 2000. Effects of a whey protein product and spray-dried animal plasma on growth performance of weanling pigs. J. Anim. Sci. 78:647-657.

Groh, H., K. Schade, and C. Hlejrhold-Schubert. 1993. Steroid metabolism with intestinal microorganisms. J. Basic Microbiol. $33: 59-72$

Guarner, F., and G. J. Schaafsma. 1998. Probiotics. Int. J. Food Microbiol. 39:237-238.

Gudiel-Urbano, M., and I. Goñi. 2002. Effect of short-chain fructooligosaccharides and cellulose on cecal enzyme activities in rats. Ann. Nutr. Metab. 46:254-258.

Hara, H., S. Haga, T. Kasai, and S. Kiriyama. 1998. Fermentation products of sugar-beet fiber by cecal bacteria lower plasma cholesterol concentration in rats. J. Nutr. 128:688-693.

Hori, T., K. Matsumoto, Y. Sakaitani, M. Sato, and M. Morotomi. 1998. Effect of dietary deoxycholic acid and cholesterol on fecal steroid concentration and its impact on the colonic crypt cell proliferation in azoxymethane-treated rats. Cancer Lett. 124:79-84.

Hsu, C. K., J. W. Liao, Y. C. Chung, C. P. Hsieh, and Y. C. Chan. 2004. Xylooligosaccharides and fructooligosaccharides affect the intestinal microbiota and precancerous colonic lesion development in rats. J. Nutr. 134:1523-1528.

Ito, S., S. Hamada, K. Yamaguchi, S. Umene, H. Ito, H. Matsui, T. Ozawa, H. Taguchi, J. Watanabe, J. Wasaki, and S. Ito. 2007. Cloning and sequencing of the cellobiose 2-epimerase gene from an obligatory anaerobe, Ruminococcus albus. Biochem. Biophys. Res. Commun. 360:640-645.

Ito, S., H. Taguchi, S. Hamada, S. Kawauchi, H. Ito, T. Senoura, J. Watanabe, M. Nishimukai, S. Ito, and H. Matsui. 2008. Enzymatic properties of cellobiose 2-epimerase from Ruminococcus albus and synthesis of rare oligosaccharides by the enzyme. Appl. Microbiol. Biotechnol. 79:433-441.
Kalliomaki, M., S. Salminen, H. Arvilommi, P. Kero, P. Koskinen, and E. Isolauri. 2001. Probiotics in primary prevention of atopic disease: A randomized placebo-controlled trial. Lancet 357:10761079 .

Langlands, S. J., M. J. Hopkins, N. Coleman, and J. H. Cummings. 2004. Prebiotic carbohydrates modify the mucosa associated microflora of the human large bowel. Gut 53:1610-1616.

Lee, Y. J., C. S. Kim, and D. K. Oh. 2004. Lactulose production by $\beta$-galactosidase in permeabilized cells of Kluyveromyces lactis. Appl. Microbiol. Biotechnol. 64:787-793.

Maidak, B. L., J. R. Cole, T. G. Lilburn, C. T. Parker Jr., P. R. Saxman, R. J. Farris, G. M. Garrity, G. J. Olsen, T. M. Schmidt, and J. M. Tiedje. 2001. The RDP-II (Ribosomal Database Project). Nucleic Acids Res. 29:173-174

Marko, M. A., R. Chipperfield, and H. C. Birnboim. 1982. A procedure for the large-scale isolation of highly purified plasmid DNA using alkaline extraction and binding to glass powder. Anal. Biochem. 121:382-387.

Méndez, A., and A. Olano. 1979. Lactulose: A review on some chemical properties and applications in infant nutrition and medicine. Dairy Sci. Abstr. 41:531-535.

Minamida, K., M. Kaneko, M. Ohashi, N. Sujaya, T. Sone, M. Wada, A. Yokota, H. Hara, K. Asano, and F. Tomita. 2005. Effects of difructose anhydride III (DFA III) administration on bile acids and growth of DFA III-assimilating bacterium Ruminococcus productus on rat intestine. J. Biosci. Bioeng. 99:548-554.

Mitsuoka, T., T. Sega, and S. Yamamoto. 1965. Eine verbesserte methodik der qualitativen und qunatitativen analyse der darmflora von menschen und tieren. Zentbl. Bakteriol. Hyg. I. Abt. Orig. 195:455-469.

Moreno, F. J., M. Villamiel, and A. Olano. 2003. Effect of high pressure on isomerization and degradation of lactose in alkaline media. J. Agric. Food Chem. 51:1894-1896.

Ohta, A., M. Uehara, K. Sakai, M. Takasaki, H. Adlercreutz, T. Morohashi, and Y. Ishimi. 2002. A combination of dietary fructooligosaccharides and isoflavone conjugates increases femoral bone mineral density and equol production in ovariectomized mice. J. Nutr. 132:2048-2054.

Reeves, P. G., F. H. Nielsen, and G. C. Fahey Jr. 1993. AIN-93 purified diets for laboratory rodents: Final report of the American Institute of Nutrition ad hoc writing committee on the reformulation of the AIN-76A rodent diet. J. Nutr. 123:1939-1951.

Rembacken, B. J., A. M. Snelling, P. M. Hawkey, D. M. Chalmers, and A. T. Axon. 1999. Non-pathogenic Escherichia coli versus mesalazine for the treatment of ulcerative colitis: A randomised trial. Lancet 354:635-639.

Rinttilä, T., A. Kassinen, E. Malinen, L. Krogius, and A. Palva. 2004. Development of an extensive set of $16 \mathrm{~S}$ rDNA-targeted primers for quantification of pathogenic and indigenous bacteria in faecal samples by real-time PCR. J. Appl. Microbiol. 97:1166-1177.

Sako, T., K. Matsumoto, and R. Tanaka. 1999. Recent progress on research and applications of non-digestible galacto-oligosaccharides. Int. Dairy J. 9:69-80.

Shornikova, A. V., I. A. Casas, E. Isolauri, H. Mykkanen, and T. Vesikari. 1997. Lactobacillus reuteri as a therapeutic agent in acute diarrhea in young children. J. Pediatr. Gastroenterol. Nutr. 24:399-404.

Stevenson, B. S., S. A. Eichorst, J. T. Wertz, T. M. Schmidt, and J. A. Breznak. 2004. New strategies for cultivation and detection of previously uncultured microbes. Appl. Environ. Microbiol. 70:4748-4755.

Tyler, T. R., and J. M. Leatherwood. 1967. Epimerization of disaccharides by enzyme preparations from Ruminococcus albus. Arch. Biochem. Biophys. 119:363-367.

Uchida, K., T. Satoh, S. Narushima, K. Itoh, H. Takase, K. Kuruma, H. Nakao, N. Yamaga, and K. Yamada. 1999. Transformation of bile acids and sterols by Clostridia (fusiform bacteria) in Wistar rats. Lipids 34:269-273.

Watanabe, J., N. Sasajima, A. Aramaki, and K. Sonoyama. 2008. Consumption of fructooligosaccharide reduces 
2,4-dinitrofluorobenzene-induced contact hypersensitivity in mice. Br. J. Nutr. 100:339-346.

Yamazaki, K., T. Inoue, N. Yasuda, Y. Sato, T. Nagakura, S. Takenaka, R. Clark, T. Saeki, and I. Tanaka. 2007. Comparison of efficacies of a dipeptidyl peptidase IV inhibitor and $\alpha$-glucosidase inhibitors in oral carbohydrate and meal tolerance tests and the effects of their combination in mice. J. Pharmacol. Sci. 104:29-38.
Ziemer, C., and G. Gibson. 1998. An overview of probiotics, prebiotics and synbiotics in the functional food concept: Perspectives and future strategies. Int. Dairy J. 8:473-479.

Zoetendal, E. G., A. von Wright, T. Vilpponen-Salmela, K. Ben-Amor, A. D. L. Akkermans, and W. M. de Vos. 2002. Mucosa-associated bacteria in the human gastrointestinal tract are uniformly distributed along the colon and differ from the community recovered from feces. Appl. Environ. Microbiol. 68:3401-3407. 